\title{
A decade of norovirus disease risk among older adults in upper-middle and high income countries: a systematic review
}

\author{
Lisa Lindsay ${ }^{1 *}$, Joanne Wolter ${ }^{2}$, Ilse De Coster ${ }^{3}$, Pierre Van Damme ${ }^{3}$ and Thomas Verstraeten ${ }^{1}$
}

\begin{abstract}
Background: Noroviruses (NoVs) are the most common cause of acute gastroenteritis (AGE) causing both sporadic and outbreak-associated illness. Norovirus (NoV) infections occur across all ages but certain sub-groups are considered at increased risk due to heightened transmission and/or symptom severity. Older adults are potentially at high risk of NoV-associated illness due to frequent outbreaks in long-term care facilities (LTCFs) and severe health outcomes following infection. Elucidation of NoV risk among older adults will support prevention, treatment and control efforts.
\end{abstract}

Methods: We conducted a systematic literature review to summarize the published risk estimates of NoV-associated illness, hospitalization and death among individuals aged 65 years and older. A structured search using defined NoV and gastroenteritis (GE) terms was performed in the PubMed and EMBASE databases of human studies published between January 1, 2003 and May 16, 2013.

Results: We identified 39 studies from high income (HI) and upper-middle income (UMI) countries. Thirty-six percent of publications provided risk estimates based on laboratory-confirmed or epidemiologically-linked population-based surveillance data using molecular diagnostic methods. Over the study period, estimated annual NoV rates and extrapolated number of cases among older adults in $\mathrm{HI}$ and UMI countries were: 29-120/10,000 or 1.2-4.8 million NoV-associated illnesses; $18-54 / 10,000$ or 723,000-2.2 million NoV-associated outpatient visits; $1-19 / 10,000$ or 40,00-763,000 NoV-associated inpatient visits; $0.04-0.32 / 10,000$ or 2000-13,000 NoV-associated deaths. NoV was responsible for approximately 10-20\% of GE hospitalizations and 10-15\% of all-cause GE deaths among older adults. Older adults experienced a heightened risk of nosocomial infections. Those in LTCFs experience frequent NoV outbreaks and the range in attack rates was 3-45\%, case hospitalization rates $0.5-6 \%$ and case fatality rates $0.3-1.6 \%$.

Conclusions: Older adults are at increased risk of severe NoV-associated health outcomes. NoV-associated hospitalization rates were higher, more severe, resulted in longer stays and incurred greater costs than for younger patients. NoV-associated mortality rates were approximately $200 \%$ higher among individuals 65 years and older compared to $<5$ years. The burden of NoV among older adults is expected to rise along with societal aging and increased need for institutionalized care. NoV prevention in older adults, including potential vaccination, may significantly impact risk of severe illness.

Keywords: Norovirus, Older adults, Gastroenteritis, Epidemiology, Risk, Disease burden

\footnotetext{
*Correspondence: lisa.lindsay@P-95.com

'P95 Pharmacovigilance and Epidemiology Services, Leuven, Belgium

Full list of author information is available at the end of the article
} 


\section{Background}

Noroviruses (NoVs) are non-enveloped, single-stranded RNA viruses that cause both sporadic and epidemic illness. NoVs are the most common cause of acute gastroenteritis (AGE) in both adults and children and are characterized by an incubation period of 1-2 days and acute onset of non-bloody diarrhea, nausea, vomiting and abdominal cramps with possible fever, malaise and anorexia [1-5]. NoVs are grouped into at least five genogroups based on the viral capsid gene and within each genogroup up to 20 genotypes have been identified [6]. Genogroups I and II are the most common in humans with genotype GII.4 accounting for the majority of norovirus (NoV) cases globally, due primarily to GII.4 2012 Sydney and 2009 New Orleans strains in recent years [2, 7-15].

NoV infections are extremely common and start to occur early in life. In a Peruvian birth cohort approximately $80 \%$ of NoV infections occurred within the first year of life [16]. By adulthood, $90 \%$ of individuals in both England and Chile have detectable antibodies against NoV [1]. While there is evidence of both innate and acquired genotype-specific (but not genogroup) immunity, there is some controversy over the specificity and duration of NoV immunity as well as the role of asymptomatic infections [1, 16-20]. NoV evolution occurs through adaptive changes in the capsid P2 domain, particularly for genotype GII.4, which allows the virus to escape herd immunity [12, 17].

NoV AGE outbreaks are extremely common due to viral evolution, low infectious dose, extended viral shedding, sustained environmental persistence, and low background immunity $[6,21-25]$. NoV has distinct seasonal activity with $75 \%$ of all cases occurring during cooler months and annual fluctuations in the number and severity of cases largely due to the emergence of novel genotypes or variants [26]. NoV is the leading cause of foodborne illness responsible for approximately 60-65\% of such illness in both the United States (US) and Canada as well as being the second leading cause of foodborne hospitalizations (26 \%) following nontyphoidal Salmonella spp (35 \%) [4, 27]. While foodborne NoV outbreaks are well documented, the most frequent setting for outbreaks is healthcare facilities (including both hospitals and long-term care facilities (LTCFs)) in which person-to-person transmission of genotype GII.4 is most common [2, 6, 28-38]. NoV GII.4 is responsible for the majority of $\mathrm{NoV}$ cases in both adults and children, however the relative importance of specific GII.4 variants and non-GII.4 genotypes may vary according to outbreak setting (GII.4 New Orleans and Sydney predominate in healthcare settings) and transmission route (GI.3, 6, 7 and GII.3, 6, 12 predominate in foodborne outbreaks) $[7,8,11]$. Furthermore, in a systematic review NoV GII.4 was reported to be associated with more severe outcomes than other genotypes in all ages [33].

While NoV causes sporadic and outbreak AGE in all age groups, specific sub-groups may be at heightened risk due to increased risk of exposure and subsequent illness and/ or heightened risk of severe outcome once infected. Such populations include the very young and old, individuals who are immunocompromised, and those living in closed/ semi-closed communities [1, 5, 39, 40]. The pediatric population experiences an extremely high incidence of both non-medically attended and medically-attended NoV illness. Recent reports indicate that, since the introduction of vaccination against rotavirus disease, which has decreased the burden of this childhood illness, NoV has become the leading cause of pediatric AGE and hospitalizations in diverse settings such as the US, Finland and Nicaragua [41-48]. There is also evidence to suggest that older adults may be at increased risk of severe NoV illness [49-51]. This may be due to intrinsic factors such as agerelated alterations in $\mathrm{B}$ and $\mathrm{T}$ cell function as a result of immunosenescence or the presence of comorbidities (such as immunosuppression, renal disease, cardiovascular disease and/or functional disability) that can reduce an individual's ability to mount a successful immune response to infection and result in more severe/extended symptoms or exacerbation of underlying conditions $[49,52,53]$. Extrinsic factors such as institutionalized housing may further influence exposure potential or be a proxy for poor underlying health status [33, 54-57]. Determining the importance of $\mathrm{NoV}$ as a causal pathogen and estimating the $\mathrm{NoV}$-associated risk among older adults is important for prevention efforts.

Development of vaccines against $\mathrm{NoV}$ is currently underway, but there are no approved $\mathrm{NoV}$ vaccines to date $[18,58-62]$. As a frequent cause of AGE in all age groups, prevention of NoV illness through vaccination could have a substantial impact on the worldwide burden of sporadic and outbreak AGE. Estimates of the disease burden among at-risk populations, such as older adults, will help target clinical development of novel vaccines and inform future vaccination policy decisions. We conducted a systematic literature review to determine the risk of NoV-associated gastroenteritis (GE), hospitalization and death in older adults.

\section{Methods}

\section{Search strategy and selection criteria}

We conducted a literature search within PubMed and Embase using the following MESH (Medical Subject Headings) terms and the free text term 'Norwalk-like disease': ((norovirus OR norwalk-like virus OR norwalk-like disease) AND epidemiology) OR (gastroenteritis AND (incidence OR prevalence OR surveillance OR epidemiology) 
NOT (Appendicitis OR Cholera Morbus OR Diverticulitis OR Esophagitis OR Inflammatory Bowel Diseases OR Mucositis OR Proctitis OR cancer OR children OR infant)). We did not limit our search to studies among older adults but reviewed all possible publications given the scarcity of data specific to this population and the inclusion of age-stratified results in community-based research. We limited articles to human studies published in English between January 1, 2003 and May 16, 2013, which had an abstract available. Publications were excluded if they described a single outbreak given that such publications, although informative, may produce less generalizable results due to outbreak specific conditions with respect to genotype circulation, population characteristics, outbreak reporting and control activities. Articles were reviewed for any information concerning $\mathrm{NoV}$ incidence, prevalence, attributable proportion and attack rates among older adults (individuals aged $\geq 65$ years). Studies conducted exclusively in LTCFs were considered to include predominantly older adults. Other extracted information included study setting, NoV diagnostic method, and outbreak status (e.g., restriction of data to periods of heightened norovirus activity or inclusion of both outbreak and non-outbreak periods) at the time of the study. We considered studies by duration ( 1 year or $>1$ years duration) and availability of numerator and denominator data. We present data according to health outcome and type of risk estimate (incidence per 10,000 followed by attributable proportion for less specific GE) for studies that clearly identify NoV-specific estimates. Furthermore, we present data separately for studies that exclusively reported nosocomial cases and long-term care facility (LTCF) outbreaks.

We calculated the number of NoV GE cases in highincome (HI) and upper-middle income (UMI) countries for NoV outpatient visits, hospitalizations and deaths among older adults by extrapolating estimated incidence rates to cumulative $\mathrm{HI}$ and UMI country population figures for those $\geq 65$ years based on 2013 World Bank population estimates (http://data.worldbank.org). HI countries were considered to be those countries with an annual gross national income per capita of $\geq \$ 12,616$ and UMI countries were considered to be countries with an annual gross national income per capita between $\$ 4086$ and $\$ 12,615$ per capita representing approximately 402 million individuals aged $\geq 65$ years ( 209 million and 193 million in HI and UMI countries, respectively).

\section{Results}

\section{Search results}

A summary of the literature review process is given in Fig. 1. Publications that provided information on NoV risk by age among older adults are summarized in Table 1 . We

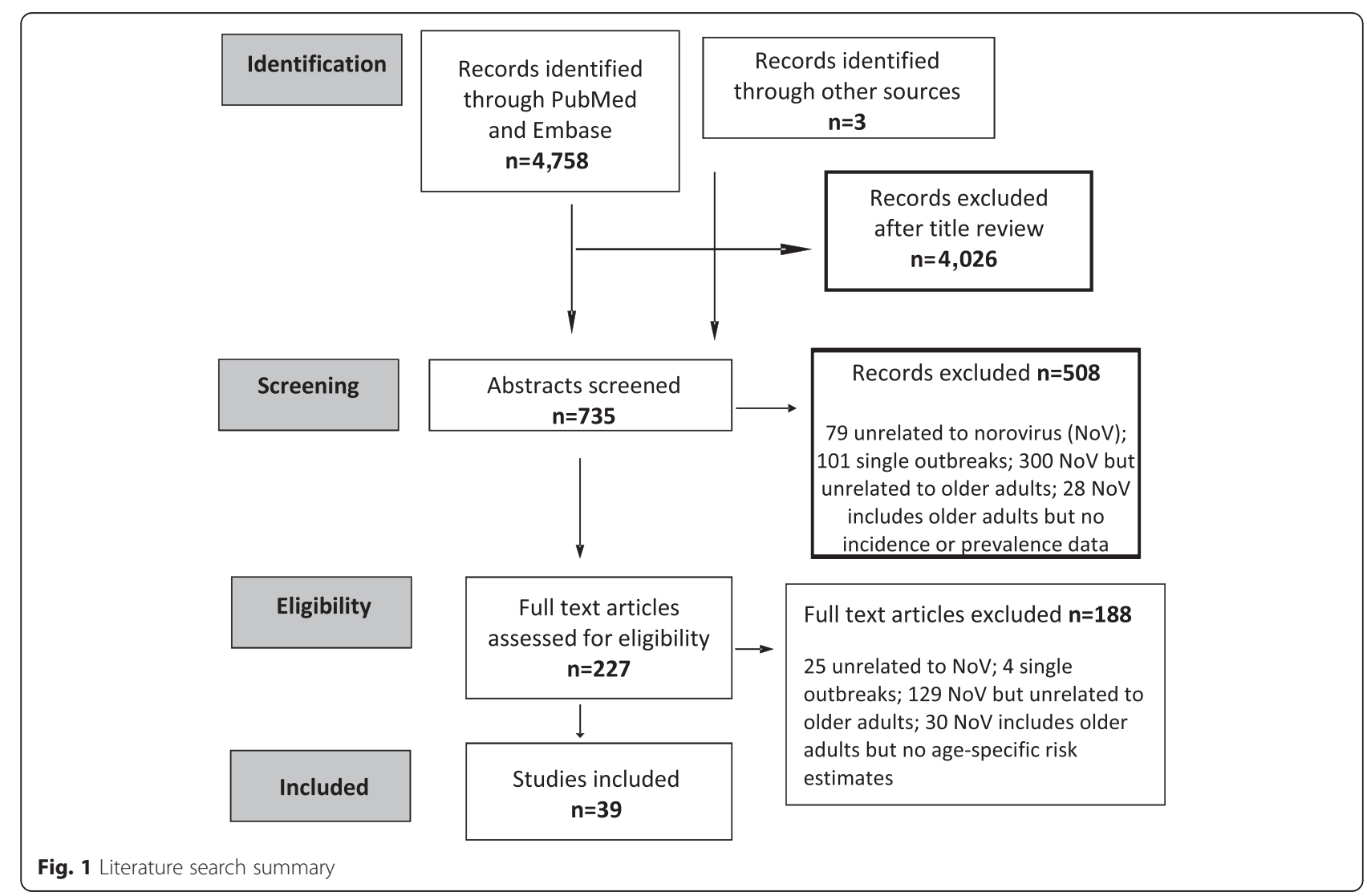


Table 1 Summary of 39 studies with norovirus (NoV) incidence or prevalence data among older adults

\begin{tabular}{|c|c|c|c|c|c|c|c|c|}
\hline Author (Ref) & Country & Study years & Study design & Lab Method & $\begin{array}{l}\text { Risk estimation } \\
\text { method }^{\mathrm{a}}\end{array}$ & Age & Data source/population & Outcome of interest \\
\hline Trivedi [89] & US & 2009-2010 & Retrospective cohort & $N S^{b}$ & C & NS & NORS and Medicare/LTCFs ${ }^{c}$ in 3 states & $\begin{array}{l}\text { All cause hospitalizations and } \\
\text { deaths during outbreaks }\end{array}$ \\
\hline Hall [51] & US & 1999-2007 & $\begin{array}{l}\text { Retrospective } \\
\text { regression analysis }\end{array}$ & NS & C & All & $\begin{array}{l}\text { National Center for Health Statistics/nationwide } \\
G^{d} \text { deaths }\end{array}$ & $\begin{array}{l}\text { Incidence and attributable proportion } \\
\text { of unspecified GE deaths }\end{array}$ \\
\hline Shahid [109] & US & 2007 & $\begin{array}{l}\text { Retrospective } \\
\text { laboratory review }\end{array}$ & Elisa & B & All & $\begin{array}{l}\text { In- and outpatient laboratory samples/city-wide } \\
\text { patients tested for NoV }\end{array}$ & $\begin{array}{l}\text { Characteristics of NoV positive } \\
\text { specimens }\end{array}$ \\
\hline Lopman [70] & US & 1996-2007 & $\begin{array}{l}\text { Retrospective } \\
\text { regression analysis }\end{array}$ & NS & C & All & $\begin{array}{l}\text { National Inpatient Sample/nationwide GE } \\
\text { hospital discharges }\end{array}$ & $\begin{array}{l}\text { Incidence and attributable proportion } \\
\text { of unspecified GE discharges }\end{array}$ \\
\hline Rosenthal [38] & US & 2003-2006 & $\begin{array}{l}\text { Prospective } \\
\text { surveillance }\end{array}$ & PCR & A & $18-106$ y & 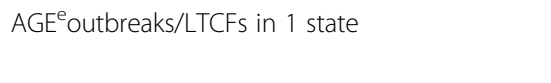 & $\begin{array}{l}\text { Attack rates, case-hospitalization and } \\
\text { fatality rates during NoV outbreaks }\end{array}$ \\
\hline Chui [71] & US & 1991-2004 & $\begin{array}{l}\text { Retrospective } \\
\text { database review }\end{array}$ & NS & D & $65-<85$ y & $\begin{array}{l}\text { Medicare and Medicaid and US Census/ } \\
\text { nationwide hospitalizations }\end{array}$ & $\begin{array}{l}\text { Incidence of specific gastrointestinal } \\
\text { disease hospitalizations }\end{array}$ \\
\hline Gastañaduy [45] & US & $2001-2009$ & $\begin{array}{l}\text { Retrospective } \\
\text { regression analysis }\end{array}$ & NS & C & All & $\begin{array}{l}\text { MarketScan Insurance Claims/US emergency } \\
\text { and outpatient visits among insured }\end{array}$ & $\begin{array}{l}\text { Incidence of emergency and } \\
\text { outpatient visits for cause-specified } \\
\text { and unspecified GE attributed to NoV }\end{array}$ \\
\hline Leshem [35] & US & 2010-2013 & $\begin{array}{l}\text { Retrospective } \\
\text { analysis surveillance }\end{array}$ & PCR & A & All & $\begin{array}{l}\text { Sentinel community NOV surveillance (NORS } \\
\text { and CaliciNet)/community outbreaks in } 5 \text { states }\end{array}$ & $\begin{array}{l}\text { Age-specific NoV distribution during } \\
\text { Gll.4 outbreaks }\end{array}$ \\
\hline Leshem [110] & US & 2010-2012 & $\begin{array}{l}\text { Retrospective analysis } \\
\text { surveillance }\end{array}$ & PCR & A & All & $\begin{array}{l}\text { Sentinel community NoV surveillance (NORS and } \\
\text { CaliciNet)/community outbreaks in } 27 \text { states }\end{array}$ & $\begin{array}{l}\text { Age-specific NoV distribution during } \\
\text { Gl.6 outbreaks }\end{array}$ \\
\hline Hall [111] & US & 1979-2010 & Literature review & NS & $\mathrm{E}$ & All & $\begin{array}{l}\text { Published studies with population-based } \\
\text { incidence rates of NoV/US studies }\end{array}$ & Summary NoV incidence estimates \\
\hline Ruzante [72] & Canada & $2001-2004$ & $\begin{array}{l}\text { Retrospective } \\
\text { database review }\end{array}$ & NS & $\mathrm{D}$ & All & $\begin{array}{l}\text { Canadian Institute for Health Information, Vital } \\
\text { Statistics Registry, National Notifiable Diseases } \\
\text { database/nationwide hospitalizations and deaths }\end{array}$ & $\begin{array}{l}\text { Age-specific hospitalization and } \\
\text { mortality incidence rates based on } \\
\text { NoV-specific diagnostic coding }\end{array}$ \\
\hline Friesema [87] & $\mathrm{NL}$ & $2005-2007$ & $\begin{array}{l}\text { Prospective } \\
\text { surveillance }\end{array}$ & PCR & A & $42-100$ y & $\begin{array}{l}\text { NoV outbreaks/LTCFs with nursing wards in } 6 \\
\text { local health services }\end{array}$ & $\begin{array}{l}\text { Characteristics of NoV outbreaks by } \\
\text { genotype and symptoms }\end{array}$ \\
\hline Van Asten [77] & $\mathrm{NL}$ & 1999-2007 & $\begin{array}{l}\text { Retrospective } \\
\text { analysis surveillance }\end{array}$ & NS & C & $\geq 65$ y & $\begin{array}{l}\text { Statistics Netherlands (mortality), weekly } \\
\text { laboratory surveillance/nationwide unspecified GE }\end{array}$ & $\begin{array}{l}\text { Attributable proportion of all-cause } \\
\text { deaths }\end{array}$ \\
\hline Van Asten [68] & $\mathrm{NL}$ & 1994-2006 & $\begin{array}{l}\text { Retrospective } \\
\text { analysis surveillance }\end{array}$ & NS & C & $\geq 65$ y & $\begin{array}{l}\text { Netherlands Information Network of GPs, NoV } \\
\text { surveillance, National Medical Register, Statistics } \\
\text { Netherland/nationwide unspecified GE }\end{array}$ & $\begin{array}{l}\text { Incidence and attributable proportion } \\
\text { of unspecified GE deaths }\end{array}$ \\
\hline Verhoef [80] & $\mathrm{NL}$ & 2009 & $\begin{array}{l}\text { Retrospective analysis } \\
\text { surveillance analysis }\end{array}$ & NS & C & All & $\begin{array}{l}\text { SENSOR study, German notifiable disease data, } \\
\text { other literature/nationwide }\end{array}$ & $\begin{array}{l}\text { Age-specific mortality, disease burden } \\
\text { and burden due to foodborne } \\
\text { NoV GE }\end{array}$ \\
\hline Spackova [82] & Germany & $2002-2008$ & $\begin{array}{l}\text { Retrospective } \\
\text { analysis surveillance }\end{array}$ & NS & A & All & $\begin{array}{l}\text { Hospitalization reports: German notifiable disease } \\
\text { data/nationwide }\end{array}$ & $\begin{array}{l}\text { Nosocomial GE due to enteric } \\
\text { pathogens including NoV }\end{array}$ \\
\hline Werber [63] & Germany & 2004-2008 & $\begin{array}{l}\text { Retrospective } \\
\text { analysis surveillance }\end{array}$ & PCR & A & All & $\begin{array}{l}\text { German notifiable disease data, Federal Statistical } \\
\text { Office/nationwide }\end{array}$ & $\begin{array}{l}\text { Incidence, deaths and potential life } \\
\text { lost due to pathogen-specific GE }\end{array}$ \\
\hline
\end{tabular}


Table 1 Summary of 39 studies with norovirus (NoV) incidence or prevalence data among older adults (Continued)

\begin{tabular}{|c|c|c|c|c|c|c|c|c|}
\hline Bernard [32] & Germany & $2001-2009$ & $\begin{array}{l}\text { Retrospective analysis } \\
\text { surveillance }\end{array}$ & PCR & A & All & $\begin{array}{l}\text { German notifiable disease data, Federal Statistical } \\
\text { Office/nationwide }\end{array}$ & $\begin{array}{l}\text { Age-specific incidence, hospitalization } \\
\text { and mortality due to NoV }\end{array}$ \\
\hline Gustavsson [55] & Sweden & $2008-2009$ & $\begin{array}{l}\text { Retrospective } \\
\text { case-control }\end{array}$ & PCR & B & $\geq 60 y$ & $\begin{array}{l}\text { Hospital database/hospitalized adults at one } \\
\text { hospital }\end{array}$ & 30 and 90 day survival rates \\
\hline Fernandez [65] & Spain & $2000-2007$ & $\begin{array}{l}\text { Retrospective } \\
\text { laboratory-based }\end{array}$ & PCR & B & All & Patient laboratory stool samples & $\begin{array}{l}\text { Age-specific prevalence of enteric } \\
\text { pathogens in GE cases }\end{array}$ \\
\hline Arias [112] & Spain & 2004-2005 & $\begin{array}{l}\text { Prospective } \\
\text { surveillance }\end{array}$ & PCR & A & All & $\begin{array}{l}\text { Mandatory physician reported outbreaks/ } \\
\text { Catalonia region }\end{array}$ & Age-specific incidence of GE \\
\hline Manso [67] & Spain & 2010-2011 & $\begin{array}{l}\text { Prospective } \\
\text { laboratory-based }\end{array}$ & PCR & B & All & $\begin{array}{l}\text { In- and outpatient laboratory stool samples/ } \\
\text { hospital complex }\end{array}$ & $\begin{array}{l}\text { Age-specific prevalence of enteric } \\
\text { pathogens in GE cases }\end{array}$ \\
\hline Huhulescu [64] & Austria & 2007 & Prospective cohort & PCR & A & All & Outpatients/3 physician clinics & Pathogen-specific prevalence in GE \\
\hline Harris [78] & England/Wales & 2001-2006 & $\begin{array}{l}\text { Retrospective } \\
\text { regression analysis }\end{array}$ & NS & C & $\geq 65$ y & $\begin{array}{l}\text { Community pathogen surveillance; mortality } \\
\text { statistics: Health Protection Agency, Office of } \\
\text { National Statistics/England and Wales }\end{array}$ & Attributable proportion of GE deaths \\
\hline Haustein [69] & England & $2000-2006$ & $\begin{array}{l}\text { Retrospective } \\
\text { regression analysis }\end{array}$ & NS & C & $\geq 18$ y & $\begin{array}{l}\text { Hospital Episode Statistics and LabBase Health } \\
\text { Protection Agency/nationwide }\end{array}$ & $\begin{array}{l}\text { Incidence and attributable } \\
\text { proportion of hospital admissions }\end{array}$ \\
\hline Philips [42] & England & 1993-1996 & Prospective cohort & PCR & A & All & Outpatients/70 GP clinics nationwide & Age-specific NoV incidence \\
\hline Philips [113] & England & 1993-1996 & Prospective cohort & PCR & A & All & $\begin{array}{l}\text { Community and outpatient non-GE patients/ } \\
\text { cohort and } 70 \text { GP clinics nationwide }\end{array}$ & Prevalence of asymptomatic NoV \\
\hline Rovida [76] & Italy & $2011-2012$ & $\begin{array}{l}\text { Retrospective } \\
\text { laboratory-based }\end{array}$ & PCR & B & All & $\begin{array}{l}\text { Inpatient laboratory samples (stool)/one } \\
\text { hospital }\end{array}$ & Pathogen-specific prevalence of GE \\
\hline Kirk [83] & Australia & $2002-2008$ & $\begin{array}{l}\text { Retrospective } \\
\text { surveillance analysis }\end{array}$ & NS & A & Adults & GE outbreaks OzFoodNet/LTCFs nationwide & $\begin{array}{l}\text { Pathogen-specific GE outbreak } \\
\text { incidence and characteristics of GE } \\
\text { outbreaks }\end{array}$ \\
\hline Davis [88] & Australia & 2004-2007 & $\begin{array}{l}\text { Retrospective } \\
\text { surveillance analysis }\end{array}$ & PCR & A & NS & GE outbreaks OzFoodNet/LTCFs in Queensland & $\begin{array}{l}\text { Characteristics of NoV outbreaks in } \\
\text { LTCFs }\end{array}$ \\
\hline Tian [66] & China & 2008-2009 & Prospective cohort & PCR & B & $\geq 14 y$ & Outpatients with AGE/GE Department one hospital & NoV prevalence by age \\
\hline Chan [74] & Hong Kong & $2012-2013$ & Prospective cohort & PCR & B & All & Inpatients with NoV+ AGE/one hospital & NoV Gll.4 distribution by age \\
\hline Ho [37] & Hong Kong & $2001-2006$ & $\begin{array}{l}\text { Prospective } \\
\text { laboratory-based } \\
\text { analysis }\end{array}$ & PCR & A & All & $\begin{array}{l}\text { Laboratory stool samples from inpatient, outpatients } \\
\text { and outbreak cases with AGE/nationwide }\end{array}$ & $\begin{array}{l}\text { Characteristics of NoV outbreaks by } \\
\text { age, genotype and season }\end{array}$ \\
\hline Tseng [114] & Taiwan & 2005-2007 & $\begin{array}{l}\text { Prospective } \\
\text { surveillance }\end{array}$ & PCR & B & $>15 y$ & $\begin{array}{l}\text { AGE cases at residential psychiatric care } \\
\text { institution/one care center }\end{array}$ & $\begin{array}{l}\text { Pathogen-specific GE hospitalization } \\
\text { rate }\end{array}$ \\
\hline Tang [75] & Taiwan & $2011-2012$ & Prospective cohort & PCR & B & All & $\begin{array}{l}\text { AGE symptomatic and asymptomatic in-, } \\
\text { out- and emergency patients/one hospital }\end{array}$ & $\begin{array}{l}\text { NoV prevalence by AGE symptom } \\
\text { status }\end{array}$ \\
\hline $\operatorname{Lim}[15]$ & Singapore & 2004-2011 & $\begin{array}{l}\text { Retrospective } \\
\text { laboratory }\end{array}$ & PCR & B & All & AGE stool samples/one hospital laboratory & $\begin{array}{l}\text { Age-specific distribution of NoV } \\
\text { positive samples }\end{array}$ \\
\hline
\end{tabular}


Table 1 Summary of 39 studies with norovirus (NoV) incidence or prevalence data among older adults (Continued)

\begin{tabular}{|c|c|c|c|c|c|c|c|c|}
\hline Al-Thani [73] & Qatar & 2009 & Prospective cohort & PCR & B & All & AGE emergency patients/one hospital & Enteric pathogen distribution by age \\
\hline Greig [85] & Global & 1997-2007 & Literature review & NS & $\mathrm{E}$ & NS & GE outbreaks in LTCFs/global & $\begin{array}{l}\text { Characteristics of enteric outbreaks } \\
\text { by pathogen and transmission }\end{array}$ \\
\hline Utsumi [86] & Global & 1966-2008 & Literature review & NS & $\mathrm{E}$ & NS & Infectious disease outbreaks in LTCFs/global & $\begin{array}{l}\text { Characteristics of infectious disease } \\
\text { outbreaks by pathogen }\end{array}$ \\
\hline
\end{tabular}

a Method: A = laboratory confirmed or epidemiologically-linked population-based surveillance; $\mathrm{B}=$ laboratory-confirmed clinic/hospital setting; $\mathrm{C}=$ indirect attribution from regression modeling; $\mathrm{D}=$ hospital database study select enteric illness codes without extrapolation $\mathrm{E}=$ literature review

${ }^{b}$ NS not specified; NS diagnostic methods may have included molecular methods; NS age often reported for LTCFs generally serving older adults

'LTCF long term care facility

${ }^{\mathrm{d}} G E$ gastroenteritis

${ }^{\mathrm{e}} A G E$ acute gastroenteritis 
identified 39 studies conducted in $15 \mathrm{HI}$ and UMI countries (44 \% Europe, $28 \%$ in the US/Canada, $23 \%$ in Australia, Asia and the Middle East, and $5 \%$ global reviews which were based predominantly in $\mathrm{HI}$ and UMI countries). Data were included in the identified studies from 1966-2013.

Risk estimates based on laboratory-confirmed or epidemiologically-linked population-based surveillance data were provided by $36 \%(14 / 39)$ of studies, $28 \%$ $(11 / 39)$ were hospital or clinic-based laboratoryconfirmed studies and $23 \%(9 / 39)$ of the studies indirectly attributed NoV risk based on regression modeling. The remaining studies provided risk estimates based on secondary database review of NoVspecific hospitalization codes $(5.1 \%, 2 / 39)$ and literature reviews $(7.7 \%, 3 / 39)$. The included literature reviews diverged from the current study in scope of research interests and methods. NoV-associated outcomes reported in these studies included infections, illness, outpatient and emergency visits, hospitalizations and deaths. Ten primary studies reported NoV incidence data and 29 studies reported other measures of risk such as proportion of AGE cases positive for NoV or attack rates. Eleven publications focused predominantly on older adults. Seven publications (5 studies and 2 reviews) pertained exclusively to LTCFs (which did not always provide study-specific age distribution) and 1 publication pertained exclusively to nosocomial GE cases. NoV was detected using molecular methods in 22 studies, 1 study used immunoassay, and 16 studies used a variety of methods (which could have included molecular methods) or the method was not specified. Thirty studies considered study periods of at least 1 year.

\section{NoV-associated illness}

No studies were identified that reported the community age-specific incidence of non-medically-attended $\mathrm{NoV}$ illness among older adults. German notifiable disease surveillance data reported community-level age-specific incidence of NoV-associated cases among individuals $\geq 65$ years, which is presumed to include symptomatic individuals of varying severity [32, 63]. This data provided information on hundreds of thousands of individuals representing both sporadic and outbreak-associated community and institutional NoV cases that were laboratory or epidemiologically-confirmed $[32,63]$. Age-specific mean incidence of $\mathrm{NoV}$ cases (2001-2009) demonstrated a U-shaped age distribution with the highest rates in the very young and older adults. NoV incidence (per 10,000) estimates from 2004-8 were approximately 54 in those $<5$ years, $5-15$ in those 5-69 years, and 48 in those $\geq 70$ years [63]. A second publication of the German surveillance data
(2001-2008) provided a similar age-specific pattern with the highest incidence estimates per 10,000 in those $<5$ years (43) and individuals $\geq 75$ years (28.9-119.8 depending on the 5-year age strata with highest estimates in those $\geq 85$ years) [32].

\section{NoV-associated outpatient visits}

Two studies report age-specific NoV-associated outpatient incidence estimates that include older adults [42, 45]. Both of these studies reported the highest rates in the very young. Model-based rates (per 10,000) from the US were 233 among those $0-4$ years, 85 among those 5-17 years, 35 among those $18-64$ years, and 54 among those $\geq 65$ years [45]. Community-based age-specific incidence rates per 10,000 from England were 320 in those $0-4$ years, 44 among 5-14 year olds, 38 among 15-44 year olds, 26 among 45-64 year olds and 37 among those $\geq 65$ years [42].

Several publications report the mean proportion of outpatient GE visits due to NoV among middle-older aged adults (the lower age for many of these studies was 60 years) which ranged from $4-37 \%$ [45, 64-67]. While most studies did not provide confidence intervals around these estimates, the proportion of GE outpatient visits due to $\mathrm{NoV}$ among older adults was not noticeably different from the estimated 6-26\% reported among other age strata [45, 64-67].

While the incidence of NoV-associated outpatient visits in older adults may not be as high as in the very young NoV outbreaks nevertheless result in large increases of unspecified GE outpatient visits in older adults [68]. In the Netherlands, the mean monthly incidence, per 10,000, of unspecified GE outpatient visits increased $70-240 \%$ above average (15.0, 17.1 and 21.7 depending on the season) during NoV outbreaks with an overall mean of 9.1 among those $\geq 65$ years. Taking the mid-point in the estimated proportion of outpatient GE visits due to NoV among older adults of $16.5 \%$ (see above range estimates of 4-37\%), the Dutch monthly incidence data for unspecified GE outpatient visits can be extrapolated $((9.1 * 0.165) * 12))$ to an overall mean annual incidence per 10,000, of 18 with increased rates during NoV outbreaks up to 43.0 among those $\geq 65$ years. These estimates depend substantially on the actual proportion of AGE due to NoV and the level/severity of NoV circulation. While it is expected that increased rates would occur across all age groups, a direct comparison by age was not possible due to the study's focus on older adults.

\section{NoV-associated emergency department (ED) visits and hospitalizations}

A single, US model-based study provided mean agespecific incidence estimates per 10,000 for $\mathrm{NoV}$-associated ED visits which were: 38 among those $<5$ years, 10 among 
those 5-17 years, 12 among those 18-64 years, and 15 among those $\geq 65$ years [45].

Four studies reported age-specific incidence rate estimates for NoV-associated hospitalizations among older adults [69-72]. Two of these studies were based on indirect model-derived estimates that accounted for underdiagnosis of NoV among hospitalized patient $[69,70]$ while the other two studies provided estimated NoV hospitalization rates based on NoV-specific diagnostic code(s) that did not include the estimated influence of NoV on non/unspecific GE diagnoses [71, 72].

English model-derived estimates of NoV-associated hospitalization records among adults estimated a rate range, per 10,000 , of $0.23-0.48$ inpatient admissions among 18-64 year olds and 1.0-4.3 among those $\geq 65$ years [69] depending on the season. These estimates were based on national GE diagnostic codes and laboratory-based pathogen data. Higher estimates were obtained from a US model-based study that estimated the seasonal mean agespecific rate per 10,000 (and range) of NoV-associated hospitalization discharges as follows: 9.4 (5.3-18.5) among those $<5$ years, $1.1(0.6-1.9)$ among 5-17 year olds, 1.0 (0.5-1.4) among 18-64 year olds, 4.7 (2.9-7.7) among 65-74 year olds, 9.2 (5.0-21.5) among 75-84 year olds, and 18.5 (10.6-37.9) among those $\geq 85$ years [70].

Two studies reported estimated incidence rates for NoV-specific hospitalizations based on International Classification of Disease (ICD)-9 and 10 codes [71, 72]. While such specific estimates are considered underestimates of true NoV-associated hospitalization rates, they are useful for further burden of disease extrapolations and provide insight into variable diagnostic practices. One such study, a US-based Medicare and Medicaid Services study of individuals aged 65 to 85 years (representing $>90 \%$ of US elderly) reported an annual rate, per 10,000, of NoV-specific hospitalizations (based on ICD-9 code 008.63) of 0.004 among 65-85 year olds [71]. These authors highlighted that a substantial proportion of non-specific GE hospitalizations are likely to be undiagnosed viral GE in this population. Canadianbased national hospitalization data provided higher annual rates, per 10,000, of NoV-specific diagnosis (ICD-9 008.63 or ICD-10 A08.1) among middle aged and older adults ( $>59$ years) of 0.61 [72]. These authors further noted that $63 \%$ of NoV-specific hospitalizations were in this oldest age group.

Differences in the NoV hospitalization rate estimates between model-based indirect estimates [71, 72] and rate estimates based on NoV-specific diagnostic codes $[69,70]$, exceed 1000 fold when comparing the estimates of hospitalizations above 65 years by Chui et al. [71] to those for individuals 65-74 years reported by Lopman et al. [70]. These large differences highlight the extreme underestimation of risk based on pathogen- specific diagnostic codes. The validity of the model-based estimates is supported by seasonal peaks in non-specific GE hospitalization diagnoses that coincide with specific viral GE such as NoV.

The proportion of non-specific AGE ED/or hospitalized patients due to NoV among older adults has been reported in several model and laboratory-based studies [45, 69, 70, 73-76]. Qatar (laboratory-confirmed) and US-based (model derived) studies estimated that 12 and $17 \%$ (respectively) of GE ED visits were due to NoV among adults aged $>60$ years [45, 73]. In England, $>20 \%$ of GE emergency hospital admissions were due to NoV among those $\geq 65$ years during peak times of NoV activity [69].

The estimated proportion of hospitalized GE cases due to NoV among those $\geq 65$ years, in model-derived US and English-based studies, was 8-13\% depending upon whether all-cause or unspecified caused GE hospitalization codes were included in the analyses $[69,70]$. Approximately $50 \%$ of hospitalized GE patients $>65$ years with stored stool samples were NoV-positive compared to approximately $<20 \%$ among younger age groups [76]. This higher estimate may reflect differences in the study population due to more select sampling of sick individuals with NoV-like symptoms, and may be less representative of a broad and diverse GE population.

NoV outbreaks are associated with large increases in unspecified GE hospitalizations in older adults. One study in the Netherlands demonstrated an increase in the mean monthly incidence of unspecified GE inpatient visits $>30 \%$ above average during NoV outbreaks (2.4, 2.7 and 2.6 per 10,000 depending on the season) with an overall mean of 1.9 among those $\geq 65$ years [68]. Taking the mid-point in the estimated proportion of hospitalization GE visits due to NoV among older adults of $21.5 \%$, the Dutch monthly incidence data for unspecified GE inpatient visits can be extrapolated $\left.\left((1.9 * 0.215)^{*} 12\right)\right)$ to an overall mean annual incidence, per 10,000, of 4.9 with increased rates during NoV outbreaks up to 7.0 [68]. These estimates are comparable to those estimated in a US model-based study of approximately $5-19$ per 10,000 [70].

NoV-associated hospitalizations in those $\geq 65$ years have been reported to be more frequent, more severe, result in longer stays and require transfer to other care facilities following discharge compared to other age groups [32, 70, 72]. In the US, NoV-associated hospitalization rates and associated costs were highest among older adults, with half of the estimated $\$ 500$ million per year spent on NoVhospitalizations among those $\geq 65$ years [70].

\section{NoV-associated mortality}

Older adults contribute the vast majority of NoVassociated deaths [51, 55, 63]. US and German-based NoV-associated mortality rate estimates demonstrate a sharp increase with age $[51,63]$. Specifically, US-based 
average annual mortality rate estimates, per 10,000 , were 0.013 in those $<5$ years, 0.002 among those 5-64 years, and 0.20 among those $\geq 65$ years (with fluctuations up to $55 \%$ in this age group during non-epidemic and epidemic years) [51]. German NoV surveillance data reported similar NoV-associated mortality rate estimates per 10,000 namely, $<0.01$ in those $<70$ years to approximately 0.32 among those $\geq 70$ years [63].

Dutch model-based estimates suggest that seasonal viruses account for nearly $5 \%$ of all-cause mortality in the elderly with influenza accounting for the most deaths (approximately $2 \%$ ), followed by respiratory syncytial virus $(1.5 \%)$, parainfluenza $(1 \%)$ and $\operatorname{NoV}(0.2 \%)$. The percentage of all deaths due to $\mathrm{NoV}$ increased with age to $0.5 \%$ among those $\geq 85$ years [77].

In the US, approximately half of all GE deaths (regardless of age) are coded as 'cause unspecified' of which older adults account for an estimated $83 \%$ [51]. Among this population, Clostridium difficile is considered the leading cause of all-cause GE deaths and in the US NoV is the second leading cause $(8 \%)$ of all-cause GE deaths [51, 78, 79]. In analyses that excluded deaths due to $C$. difficile, NoV contributed $16 \%$ of GE deaths among older adults [51]. These findings are comparable to data from England and Wales that modeled seasonal variations in death according to seasonal variations in laboratory reports (excluding deaths due to Clostridium difficile) where NoV accounted for $20 \%$ of older adult deaths due to infectious intestinal disease and $13 \%$ of deaths registered as 'non-infectious gastrointestinal disease' [78].

Data from the Netherlands estimated that $14 \%$ of unspecified GE deaths were attributable to NoV among older adults with outbreak-associated increases of approximately $130 \%$ above the mean monthly unspecified GE death incidence per 10,000 ( $>0.06$ compared with 0.026) [68]. Based on an attributable proportion of $14 \%$, this equates to a mean annual $\mathrm{NoV}$ incidence per 10,000 of 0.04 with increases to $>0.10$ during outbreaks. While these mean estimates are lower than the estimated rates per 10,000 based on German (0.32) and US $(0.20)$ data, the estimated rates during outbreaks reached a comparable level [51, 63, 68].

One publication extrapolated German surveillance data to the Dutch population to obtain estimated mean agespecific NoV case fatality rate per 1000 (95 \% CI) of: 0.09 (0.01-0.27) for those $<1$ year, $0.00(0-1.12)$ for those $1-$ 4 years, $0.00(0-0.04)$ for those $5-11$ years, $0.09(0-0.34)$ for those 12-17 years, $0.03(0.01-0.06)$ for those 1864 years and $0.63(0.55-0.73)$ for those $\geq 65$ years [80].

In a Swedish-based study of hospitalized adults with community-onset NoV infection, nearly $8 \%$ of individuals died within 30 days of a NoV-positive sample (e.g., an $8 \% 30$-day NoV mortality rate) and all deaths occurred among those $\geq 60$ years [55]. Individuals with underlying medical conditions had a higher 30-day mortality rate than those without such conditions $(10.5 \%$ compared to $5.3 \%$ ). The study authors did not specify the relevant underlying conditions. However, another study by Harris et al., noted that circulatory, respiratory and neoplastic conditions were important contributors to NoV-associated deaths [78].

\section{Institutional NoV outbreaks}

National surveillance data from HI countries have reported that the majority of NoV outbreaks occur in hospitals and LTCFs [31, 32, 35]. NoV GII.4 has been identified in a majority of institutional outbreaks among older adults [32, 35].

\section{Nosocomial NoV}

NoV outbreaks frequently occur in hospitals and attack rates can be extremely high (up to $60 \%$ of patients and $40 \%$ of staff) $[31,32,39,81]$. In a study of nearly 40,000 NoV cases captured within the German surveillance system, age $\geq 70$ years was significantly associated with nosocomial (e.g., NoV onset $>2$ days after hospital admission) NoV infection (risk ratio $[R R]=14.3$, $95 \%$ CI 13.5-15.0 for individuals 70-81 years and RR = 13.0, $95 \%$ CI $12.4-13.6$ for individuals $>81$ years compared to those $\leq 25$ years) [82]. The proportion of NoV cases considered to be nosocomial showed a U-shaped curve with the largest proportions in those $\geq 70$ years (65\%) followed by infants $<1$ year $(16 \%)$. Approximately $66 \%$ of all NoV nosocomial infections occurred in elderly adults and the importance of nosocomial infections among this population was more pronounced for $\mathrm{NoV}$ than for other routinely surveyed GE pathogens such as rotavirus, Salmonella and Campylobacter. German surveillance data indicate that $83 \%$ of NoV hospitalized cases among those $>74$ years originated from institutional settings such as hospitals or LTCFs [32].

\section{NoV outbreaks in LTCFs}

LTCFs are a common setting for AGE outbreaks (50\% of all AGE outbreaks occurred in LTCFs as reported in a nationwide Australian study) of which $30-80 \%$ were due to NoV, largely driven by NoV GII.4 [15, 31, 35, 38, 83-87]. Within the US and Australia, the annual number of NoV outbreaks was estimated to be $6-8$ per 100 LTCFs [38, 83].

Seven studies were identified that pertained exclusively to LTCFs [38, 83, 85-89]. The definition of LTCF, facility characteristics, and resident population differed between studies, however LTCF generally referred to facilities that provided prolonged care for individuals who required daily living and/or nursing care support. None of the 7 identified studies provided the age distribution for the 
study population and only one [89] provided agestratified results. NoV outbreaks in LTCF settings were characterized by high levels of person-to-person transmission (in many reports $>90 \%$ of such outbreaks were transmitted person-to-person) facilitated through caregiving, close contact between residents and staff, as well as frequent movement of infected individuals within and between facilities [31, 38, 83, 85]. NoV outbreaks in LTCFs were associated with higher attack rates and deaths than other causes of AGE outbreaks [31, 38, 63, $83,88,89$ ]. NoV was responsible for $70 \%$ of all viral and bacterial enteric illnesses, $58 \%$ of all hospitalizations, and $27 \%$ of deaths in a review of enteric illness outbreaks in LTCFs [85]. This represents a much higher impact on severe health outcomes among LTCFs compared to other settings (versus 8-17 \% of AGE hospitalizations and $8-20 \%$ of GE deaths due to NoV in non-LTCF settings) [45, 51, 68-70, 73, 78].

Table 2 summarizes the attack, case hospitalization and case fatality rates reported for $\mathrm{NoV}$ in the identified LTCF studies. Attack rates ranged from 3 to $45 \%$ depending on the study and largely reflected differences in the number reporting/laboratory confirmation and definition of individual outbreaks, facility characteristics, and study population [38, 83, 85-88].
The median attack rate estimates from a global review by Utsumi et al. [86] for residents (45\%) and staff (42\%) included outbreaks with attack rates of $100 \%$ which may overestimate 'typical' attack rates. However, these high estimates are similar to GII.4 attack rates among individual wards of nursing homes estimated from the Netherlands [87].

Case hospitalization rates ranged from $0.5 \%$ [87] to $6 \%$ [86]. The highest median hospitalization rates were reported again in the review by Utsumi et al. which may reflect reporting differences in the primary studies [86]. However, data from a US-based study and a second global review suggest case hospitalization rates range between 2-4 \% depending on the sub-population within LTCFs $[38,85]$. Considered from a different perspective, of all enteric outbreaks in LTCFs, NoV is responsible for $58 \%$ of hospitalizations [85]. An estimated 34.4 NoVassociated hospitalizations occur annually per 10,000 individuals in LTCFs [88].

Case fatality rates due to NoV in residents of LTCFs ranged from $0.3 \%$ [83] to $1.6 \%$ [87]. The variability in case fatality rate is presumably due to study-specific definitions of NoV-associated deaths, which included broad all-cause mortality during outbreaks in highest estimates obtained in the Netherlands [87].

Table 2 Attack, case hospitalization and case fatality rates during norovirus -associated outbreaks in long-term care facilities

\begin{tabular}{|c|c|c|c|c|c|c|}
\hline \multirow[t]{2}{*}{ Author (Ref) } & \multirow[t]{2}{*}{ Location } & \multirow{2}{*}{$\begin{array}{l}\text { Number of } \\
\text { norovirus (NoV) } \\
\text { outbreaks }\end{array}$} & \multirow{2}{*}{$\begin{array}{l}\text { Population } \\
\text { included in } \\
\text { estimates }\end{array}$} & \multicolumn{3}{|l|}{ NoV-associated outcome $^{a}$} \\
\hline & & & & Attack rate (\%) & $\begin{array}{l}\text { Case hospitalization } \\
\text { rate }(\%)\end{array}$ & $\begin{array}{l}\text { Case fatality } \\
\text { rate }(\%)\end{array}$ \\
\hline Davis [88] & $\begin{array}{l}\text { Queensland, } \\
\text { Australia }\end{array}$ & 264 & Residents and staff & $\begin{array}{l}20.3 \text { any NoV-associated } \\
\text { illness }\end{array}$ & 1.7 & 0.5 \\
\hline Kirk [83] & $\begin{array}{l}\text { Nationwide, } \\
\text { Australia }\end{array}$ & 1136 & Residents and staff & - & - & 0.3 \\
\hline \multirow[t]{3}{*}{ Rosenthal [38] ${ }^{b}$} & \multirow[t]{3}{*}{ Oregon, US } & \multirow[t]{3}{*}{163} & \multirow[t]{3}{*}{ Residents } & 4; All facilities & 3.1; All facilities & 0.5; All facilities \\
\hline & & & & 6; Nursing facilities & 1.8; Nursing facilities & 0.5; Nursing facilities \\
\hline & & & & 3; Non-nursing facilities & 4.3; Non-nursing facilities & 0.4 ; Non-nursing facilities \\
\hline \multirow[t]{6}{*}{ Friesma $[87]^{c}$} & \multirow{6}{*}{$\begin{array}{l}\text { 5-6 local health } \\
\text { services, NL }\end{array}$} & \multirow[t]{6}{*}{28} & \multirow[t]{6}{*}{ Residents } & Nursing homes & \multirow[t]{6}{*}{0.5} & \multirow[t]{6}{*}{1.6} \\
\hline & & & & $15.5 \mathrm{Gll} .4$ & & \\
\hline & & & & 12.8 Non-GIl.4 & & \\
\hline & & & & $\begin{array}{l}\text { Individual wards of } \\
\text { nursing homes }\end{array}$ & & \\
\hline & & & & 40.0 Gll.4 & & \\
\hline & & & & 31.1 Non-Gll.4 & & \\
\hline Greig [85] & Global review & 43 & Residents & - & 4.2 & 0.7 \\
\hline \multirow[t]{2}{*}{ 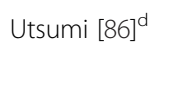 } & \multirow[t]{2}{*}{ Global review } & \multirow[t]{2}{*}{23} & Residents & 45 Residents & \multirow[t]{2}{*}{6} & \multirow[t]{2}{*}{-} \\
\hline & & & Staff & 42 Staff & & \\
\hline
\end{tabular}


Trivedi et al. [89] modeled the rates of all-cause hospitalization and mortality during NoV outbreaks compared to non-outbreak periods among LTCF residents (for facilities with $\geq 1$ reported outbreak) within 3 US states. All-cause hospitalization (adjusted RR [aRR] = 1.09; $95 \%$ CI 1.05-1.14) and mortality $(\mathrm{aRR}=1.11 ; 95 \%$ CI 1.051.18) rates were significantly increased during NoV outbreak periods. Increased rates were particularly apparent among residents $\geq 90$ years $(\mathrm{aRR}=1.24 ; 95 \% \mathrm{CI} 1.13,1.37$ for all-cause hospitalizations and $\mathrm{aRR}=1.28$; $95 \% \mathrm{CI} 1.14$, 1.42 for all-cause mortality). The estimated $12 \%$ increase in all-cause hospitalizations and $25 \%$ increase in deaths occurred primarily during the first 2 weeks of outbreaks, with estimates of 1 excess hospitalization for every 4 outbreaks and 1 excess death for every 9 outbreaks.

A few key factors were found to influence NoV risk and/or severity in the LTCF setting which include NoV genotype, age, comorbidity and facility characteristics. NoV GII.4 outbreaks in LTCFs have been associated with more frequent, severe and longer duration of illness compared to non-GII.4 outbreaks [38, 87]. The mean age of NoV cases in LTCFs has been reported to be in the mid-80s, and severe outcomes (including all-cause hospitalizations and mortality) were most frequently reported in the very aged [38, 87, 89]. Facility characteristics, such as level and adequacy ratings of nursing support within LTCFs were associated with the variable risk and severity of NoV outbreaks suggesting that poor underlying health status of residents may influence NoV susceptibility and transmission and inadequate nursing care is an important determinant of $\mathrm{NoV}$-associated mortality [38, 89].

\section{Estimated number of NoV cases in $\mathrm{HI}$ and UMI settings}

According to 2013 World Bank estimates, there were approximately 209 million individuals $\geq 65$ years living in HI countries (16\% of total HI population) and 193 million individuals $\geq 65$ years living in UMI countries (8\% of total UMI population).

Figure 2 provides estimated rates of NoV-associated health outcomes among older adults and extrapolated annual cases in HI and UMI countries. The wide range of the estimates reflect the differences in 1) study population; 2) detection and attribution methodology of NoV to GE episodes; and 3) NoV activity level and genotype distribution.

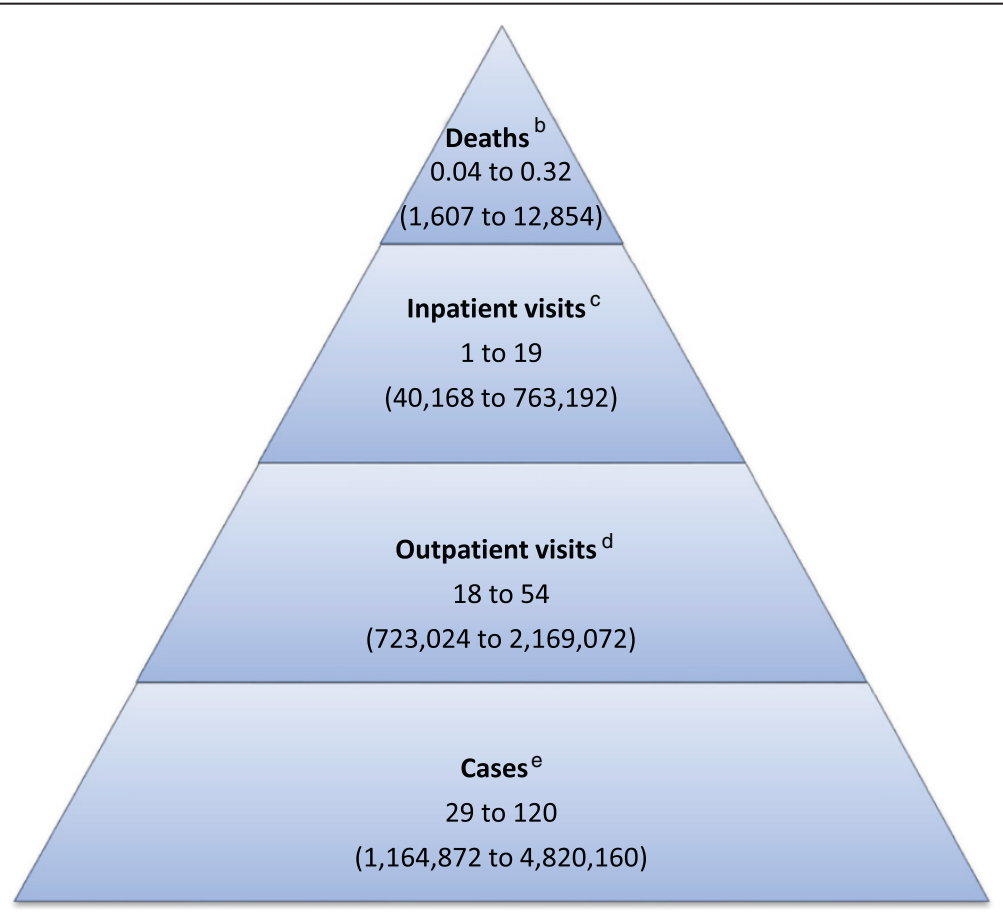

Fig. 2 Estimated annual incidence rate per 10,000 (extrapolated number) of norovirus-associated gastroenteritis cases in older adults living in high and upper-middle income countries. ${ }^{a}$. Population based on 2013 World Bank estimate of 401,680,000 individuals aged $\geq 65$ years in high $(208,960,000)$ and upper-middle income $(192,720,000)$ countries. ${ }^{b}$ Annual mortality rate estimates based on following sources: Hall et al. [51], Werber et al. [63], van Asten et al. [68]. 'Annual inpatient rate estimates based on following sources: Haustein et al. [69], Lopman et al. [70], van Asten et al. [68]. ' Annual outpatient rate estimates based on following sources: Gastanaduy et al. [45], Phillips et al. [42], van Asten et al. [68]. 'Annual case rate estimates based on following sources: Werber et al. [63], Bernard et al. [32]; if estimate accounts for incidence data published in de Wit et al. [94] which was published prior to the inclusion dates for this review, the upper incidence rate estimate would be 310 per 10,000 which corresponds to 12,452,080 estimated cases in high and upper middle income countries annually 


\section{Discussion}

We identified 39 studies from HI and UMI countries that reported information on sporadic and outbreak-associated NoV risk among older adults. Our findings demonstrate a high burden of NoV-associated illness in all ages with the highest burden of severe $\mathrm{NoV}$-associated outcomes occurring among older adults. The incidence of NoV-associated hospitalization in older adults was more frequent, more severe, resulted in longer stays and incurred greater costs than for younger patients [32, 68-70, 72]. Older adults are a key driver of overall NoV-hospitalization rates reported across different settings $[8,33,82,90]$. Estimated NoV-associated mortality rates were roughly $200 \%$ higher among those $\geq 65$ years compared to $<5$ year olds. In older adults, NoVs cause approximately $10-20 \%$ of GE hospitalizations, $10-15 \%$ of GE deaths, and $\geq 0.2 \%$ of allcause mortality $[45,51,68,69,73,77-79]$. While our review was limited to English-language publications thereby potentially missing relevant manuscripts published in other languages, our review highlights the substantial risk of NoV among institutionalized older adults in $\mathrm{HI}$ and UMI countries and supports the adverse impact NoVassociated illness has on healthcare costs and institutional control efforts including a substantial disruption in LTCF staff time and cost (including staff illness) as a result of NoV outbreaks [31, 38, 70, 83-89, 91-93].

We did not identify any community-based incidence data for non-medically attended $\mathrm{NoV}$-associated illness in older adults. Previously published data (2001), however, provide age-specific GE incidence rates (non-pathogen specific) in the general population per 10,000 of: 7400 among those $<1$ year, 9000 among those $1-4$ years, 4810 among those 5-11 years, 1570 among those $12-17$ years, 2340 among those $18-64$ years and 1940 among $\geq 65$ year olds [94]. The estimated percentage of GE cases positive for Norwalk-like virus or Sapporo-like virus was $16 \%$ (across all ages but within the range of 4-37\% detected in elderly outpatient visits). Thus, it can be roughly estimated that older adults experienced an incidence of 310/10,000 $(1940 * 0.16)$ of community-based NoV-associated illnesses representing an approximate percentage increase of 400 to $700 \%$ from the estimated rate of NoV-associated outpatient visits $(37-54 / 10,000)$ among older adults. While a direct comparison of NoV rates between age groups was not the aim of this review, data suggests that nonmedically attended NoV illness and outpatient rates are lower for older adults compared to children $<5$ years.

We found heightened NoV-associated hospitalizations and deaths among older adults with underlying health conditions which is in agreement with a recent review by Trivedi et al. [95] that identified immunosuppressive conditions to be common among NoV-associated deaths in older adults. The immediate cause of death reported among these individuals included aspiration/pneumonia, sepsis, gastrointestinal and cardiac complications. There is, however, limited reporting of susceptibility to, and clinical course of, NoV among older adults according to underlying health status. Data is also limited on the impact of NoV-associated AGE on daily living, function and quality of life among this population.

The ability to compare or pool study estimates in our review was limited by the variability inherent in the data which reflects different study designs and study populations, inaccuracies in NoV detection/attribution and potentially marked differences in NoV activity over different time periods. Among the publications included in our review, factors of interest were often omitted such as: age distribution, living situation (community or LTCF), health status and/or contributing factors, NoV circulation and genotype, and definition of AGE or GE. Moreover, while much data described AGE outbreaks in healthcare settings, endemic (e.g., cases identified outside of a recognized outbreak setting) rates of NoV illness tended to be less well described. It was difficult to differentiate sporadic (endemic) and outbreak-related NoV risk estimates in studies that reported variable levels of NoV circulation, such as surveillance data or secondary healthcare utilization databases. However it is clear that NoV-associated illnesses and severe outcomes peak during periods of high viral circulation and that NoV outbreaks significantly increase GE and all-cause hospitalizations and mortality among older adults.

One specific source of bias that is well recognized for common non-specific infectious illnesses, is the impact of both under-ascertainment (of illnesses that do not result in a healthcare visit) and under-reporting (correctly diagnosing and reporting NoV cases with non-specific symptoms) [96]. While age-specific (and, ideally, health outcome-specific) NoV multiplication factors are not routinely used, the underestimation of NoV-risk for all ages, including older adults, can be substantial. This is evident by 1 ) the estimated $400-700 \%$ increase in the NoV incidence rate of community-level illness [94] compared to the estimated rate of NoV-associated outpatient visits among the elderly [42] and, 2) the estimated $\geq 1000$ fold difference in NoV hospitalization rate estimates based on NoV-specific diagnostic codes [71, 72] and model-based indirect estimates that account for undiagnosed NoV cases [69, 70]. Among older adults NoV GII.4 is the most predominant genotype in outbreak, inpatient, LTCFs and community settings, potentially due to a combination of novel GII.4 mutations that emerge (such as the insertion of an amino acid in recent GII.4 strains) and limited immune response among older adults due to immunosenescence [35, 38, 66, 90, 97]. NoV GII.4 has also been identified as the dominant genotype causing illness in children with slightly greater 
genotype variability (particularly in the GII genogroup) due, perhaps, to less dynamic evolution of non-GII.4 genotypes [8, 11, 90, 97]. Interpretation of NoV risk and genotype distribution across settings is contingent not only upon ascertainment and reporting of individual cases but also upon systematic capture of viral circulation and illness through established surveillance systems. NoV surveillance is largely designed to identify and control outbreaks, and notifiable disease reporting may differentially capture and diagnostically confirm symptomatic infections in closed/semi-closed settings rather than open settings, thereby providing risk estimates and genotype information specific to such settings. NoV-associated illness, hospitalizations and deaths among older adults outside of institutional settings may be missed, resulting in an underestimate of risk and less-than-complete understanding of genotype distribution. Given that older adults seek healthcare for GE less frequently than the very young [98], it may be even more likely that sporadic $\mathrm{NoV}$-associated illness in community-living older adults is underestimated.

Globally, we are experiencing a rapid increase in the relative proportion of older adults due to smaller family size (i.e., fewer children) and longer life expectancy. It is estimated that the proportion of individuals $>60$ years will double between 2010 and 2050 reaching an estimated 20-30 \% in many Organisation for Economic Co-operation and Development (OECD) countries and even 38-40\% in countries such as Japan and Korea [99]. This trend is also projected for the very aged ( $>80$ years) with concomitant increases in the need for long term care (expected to quadruple by 2050 from an estimated $0.2-2 \%$ of total OECD population to $0.8-8 \%$ of total OECD countries population). Preparations are needed for the impact of the 'age wave' on the burden of disease caused by common infectious diseases such as NoV [99-101]. Thus, the burden of NoV illness in older adults is likely to increase as the number and proportion of aged, and the very aged ( $>80$ years), increases. While we have provided rough estimates of the absolute number of $\mathrm{NoV}$-associated GE cases in older adults living in $\mathrm{HI}$ and UMI countries based on extrapolated annual incidence rates, these figures should be interpreted with caution as the estimates do not account for factors such as country-specific age structure, health status or institutional residence status among older adults.

Several virus-like particles (VLP) NoV vaccines are in development which target key genotypes using a variety of production methods and administration routes [102]. Recent Phase 2 study results of a bivalent (GI and GII.4) VLP NoV vaccine have demonstrated that a candidate vaccine was generally well tolerated with efficacy observed against symptomatic illness among human volunteers vaccinated and subsequently challenged with live NoV [102, 103]. Given the increased risk of NoV-associated hospitalizations and death among older adults, regulatory approval of a safe and effective NoV vaccine which has broad coverage for common and emerging genotypes, that provides durable immunity and is efficacious among older adults, could have a positive impact in this population [104]. NoV vaccination may be a particularly attractive prevention tool for institutionalized older adults, and staff who have contact with them, for whom current control activities have shown limited/variable impact on outbreak duration and attack rates [78, 105]. This has been the case for influenza in which, like NoV, older adults account for approximately $90 \%$ of deaths and $50 \%$ of hospitalizations. Influenza vaccination has resulted in a $77 \%$ reduction in influenza-associated hospitalizations in adults aged $\geq 50$ years $[51,55,63,70,106,107]$. While $\mathrm{NoV}$-associated age-specific mortality and hospitalization rates among the elderly are generally lower than those reported for influenza, NoV estimates can reach a comparable level among the very aged during epidemic $\mathrm{NoV}$ seasons (such as 2006/7) [70, 108].

\section{Conclusion}

We described the NoV-associated burden of disease among older adults and highlighted the importance of severe NoVassociated outcomes in this population. We estimated that in $\mathrm{HI}$ and UMI countries there are 1.2 to 4.8 million NoVassociated illnesses (accounting for under-ascertainment this estimate could increase to 12.5 million), 723,000 to 2.2 million NoV-associated outpatient visits, 40,000 to 763,000 NoV-associated hospitalizations, and 2000 to $13,000 \mathrm{NoV}$ associated deaths annually. Older adults living in LTCFs are at increased risk of NoV-associated illness due to frequent outbreaks and severe health outcomes. NoV prevention has the potential to significantly reduce the NoV-associated burden of disease in all ages with perhaps the most impact on severe outcomes in older adults. This potential impact will be heightened in the coming years due to rapid aging of societies and projected increases in aged individuals requiring long term care.

\section{Abbreviations}

AGE: Acute gastroenteritis; aRR: Adjusted risk ratio; ED: Emergency department; GE: Gastroenteritis; HBGAs: Histo-blood group antigens; HI: High income; ICD: International classification of diseases; LTCF: Long-term care facility, LTCFs Long-term care facilities; NoV: Norovirus, NoVs-Noroviruses; OECD: Organisation for Economic Co-operation and Development; RR: Risk ratio; UMI: Upper-middle income; US: United States.

\section{Competing interests}

LL, JW and TV received financial support through contract services to P95 Pharmacovigilance and Epidemiology Services from Takeda Vaccines Inc. Deerfield, IL (a corporation undertaking commercial development of a norovirus vaccine) to perform the literature research in this study. IDC and PVD have no financial declaration for this report but their institution has received research grants from Takeda Vaccines for performing clinical studies of vaccine candidates. 


\section{Authors' contributions}

$\mathrm{LL}$ conducted the literature search, participated in the design and interpretation of the data, and drafted the manuscript. JW conducted the literature search and data extraction and reviewed the manuscript. IDC participated in the design and interpretation of data and reviewed the manuscript. PVD participated in the design and interpretation of data and reviewed the manuscript. TV conceived the study and participated in its design and in the interpretation of data. All authors read and approved the final manuscript.

\section{Acknowledgements}

This review was funded by Takeda Vaccines Inc. Deerfield IL.

The authors thank Marc Baay for his review of the manuscript and medical writing support, as well as Margarita Riera for her assistance on the literature search.

\section{Author details}

${ }^{1}$ P95 Pharmacovigilance and Epidemiology Services, Leuven, Belgium.

${ }^{2}$ Contractor to P95 Pharmacovigilance and Epidemiology Services, Brisbane, Australia. ${ }^{3}$ University of Antwerp, Antwerp, Belgium.

\section{Received: 19 March 2015 Accepted: 30 September 2015 Published online: 14 October 2015}

\section{References}

1. Koo HL, Ajami N, Atmar RL, DuPont HL. Noroviruses: The leading cause of gastroenteritis worldwide. Discovery Med. 2010;10(50):61-70.

2. Wikswo ME, Hall AJ. Outbreaks of Acute Gastroenteritis Transmitted by Personto-Person Contact - United States, 2009-2010. Morbidity and mortality weekly report Surveillance summaries (Washington, DC : 2002). 2012;61(9):1-12.

3. Centers for Disease Control and Prevention (CDC). Incidence and trends of infection with pathogens transmitted commonly through food - foodborne diseases active surveillance network, 10 U.S. sites, 1996-2012. MMWR Morb Mortal Wkly Rep. 2013;62(15):283-7.

4. Scallan E, Hoekstra RM, Angulo FJ, Tauxe RV, Widdowson MA, Roy SL, et al. Foodborne illness acquired in the United States-major pathogens. Emerg Infect Dis. 2011:17(1):7-15.

5. Glass RI, Parashar UD, Estes MK. Norovirus gastroenteritis. N Engl J Med. 2009;361(18):1776-85.

6. Division of Viral Diseases, National Center for Immunization and Respiratory Diseases, Centers for Disease Control and Prevention. Updated norovirus outbreak management and disease prevention guidelines. MMWR Recomm Rep. 2011;60(RR-3):1-18.

7. van Beek J, Ambert-Balay K, Botteldoorn N, Eden J, Fonager J, Hewitt J, et al. Indications for worldwide increased norovirus activity associated with emergence of a new variant of genotype II.4, late. Euro Surveillance. 2012;18(1):8-9.

8. Vega E, Barclay L, Gregoricus N, Shirley SH, Lee D, Vinje J. Genotypic and epidemiologic trends of norovirus outbreaks in the United States, 2009 to 2013. J Clin Microbiol. 2014;52(1):147-55.

9. Inaida S, Shobugawa Y, Matsuno S, Saito R, Suzuki H. The South to North variation of norovirus epidemics from 2006-07 to 2008-09 in Japan. PLoS One. 2013;8(8):e71696.

10. Mai H, Jin M, Guo X, Liu J, Liu N, Cong X, et al. Clinical and epidemiologic characteristics of norovirus Gll.4 Sydney during winter 2012-13 in Beijing, China following its global emergence. PLoS One. 2013;8(8):e71483.

11. Hoa Tran TN, Trainor E, Nakagomi T, Cunliffe NA, Nakagomi O. Molecular epidemiology of noroviruses associated with acute sporadic gastroenteritis in children: global distribution of genogroups, genotypes and Gll.4 variants. J Clin Virol. 2013:56(3):185-93.

12. Eden JS, Tanaka MM, Boni MF, Rawlinson WD, White PA. Recombination within the pandemic norovirus Gll.4 lineage. J Virol. 2013;87(11):6270-82.

13. Zheng DP, Widdowson MA, Glass RI, Vinje J. Molecular epidemiology of genogroup II-genotype 4 noroviruses in the United States between 1994 and 2006. J Clin Microbiol. 2010;48(1):168-77.

14. Siebenga JJ, Vennema $H$, Zheng DP, Vinje J, Lee BE, Pang XL, et al. Norovirus illness is a global problem: emergence and spread of norovirus Gll.4 variants, 2001-2007. J Infect Dis. 2009;200(5):802-12.

15. Lim KL, Eden JS, Oon LL, White PA. Molecular epidemiology of norovirus in Singapore, 2004-2011. J Med Virol. 2013;85(10):1842-51.

16. Saito M, Goel-Apaza S, Espetia S, Velasquez D, Cabrera L, Loli S, et al. Multiple norovirus infections in a birth cohort in a Peruvian periurban community. Clin infect Dis. 2014;58(4):483-91.
17. Lindesmith LC, Beltramello M, Donaldson EF, Corti D, Swanstrom J, Debbink K, et al. Immunogenetic mechanisms driving norovirus Gll.4 antigenic variation. PLoS Pathog. 2012;8(5):e1002705

18. Atmar RL, Bernstein DI, Harro CD, Al-lbrahim MS, Chen WH, Ferreira J, et al. Norovirus vaccine against experimental human Norwalk Virus illness. N Engl J Med. 2011:365(23):2178-87.

19. Simmons K, Gambhir M, Leon J, Lopman B. Duration of immunity to norovirus gastroenteritis. Emerg Infect Dis. 2013;19(8):1260-7.

20. Teunis PF, Sukhrie FH, Vennema H, Bogerman J, Beersma MF, Koopmans MP. Shedding of norovirus in symptomatic and asymptomatic infections. Epidemiol Infect. 2015;143(8):1710-7.

21. Matthews JE, Dickey BW, Miller RD, Felzer JR, Dawson BP, Lee AS, et al. The epidemiology of published norovirus outbreaks: a review of risk factors associated with attack rate and genogroup. Epidemiol Infect. 2012:140(7):1161-72

22. Tu ET, Bull RA, Kim MJ, Mclver CJ, Heron L, Rawlinson WD, et al. Norovirus excretion in an aged-care setting. J Clin Microbiol. 2008;46(6):2119-21.

23. Lai CC, Wang YH, Wu CY, Hung CH, Jiang DD, Wu FT. A norovirus outbreak in a nursing home: norovirus shedding time associated with age. J Clin Virol. 2013;56(2):96-101.

24. Wu HM, Fornek M, Schwab KJ, Chapin AR, Gibson K, Schwab E, et al. A norovirus outbreak at a long-term-care facility: the role of environmental surface contamination. Infect Control Hospital Epidemiol. 2005:26(10):802-10.

25. Atmar RL, Opekun AR, Gilger MA, Estes MK, Crawford SE, Neill FH, et al. Norwalk virus shedding after experimental human infection. Emerg Infect Dis. 2008;14(10):1553-7.

26. Ahmed SM, Lopman BA, Levy K. A systematic review and meta-analysis of the global seasonality of norovirus. PLoS One. 2013;8(10):e75922.

27. Thomas MK, Murray R, Flockhart L, Pintar K, Pollari F, Fazil A, et al. Estimates of the burden of foodborne illness in Canada for 30 specified pathogens and unspecified agents, circa 2006. foodborne Pathogens Dis. 2013;10(7):639-48

28. Hall AJ, Eisenbart VG, Etingue AL, Gould LH, Lopman BA, Parashar UD. Epidemiology of foodborne norovirus outbreaks, United States, 2001-2008. Emerg Infect Dis. 2012;18(10):1566-73.

29. Bruggink $L$, Marshall J. The relationship between health care and nonhealth care norovirus outbreak settings and norovirus genotype in Victoria, Australia, 2002-2005. J Microbiol Immunol Infect. 2011:44(4):241-6.

30. Bruggink LD, Oluwatoyin O, Sameer R, Witlox KJ, Marshall JA. Molecular and epidemiological features of gastroenteritis outbreaks involving genogroup I norovirus in Victoria, Australia, 2002-2010. J Med Virol. 2012;84(9):1437-48.

31. Lopman BA, Adak GK, Reacher MH, Brown DW. Two epidemiologic patterns of norovirus outbreaks: surveillance in England and wales, 1992-2000. Emerg Infect Dis. 2003;9(1):71-7.

32. Bernard $H$, Hohne M, Niendorf S, Altmann D, Stark K. Epidemiology of norovirus gastroenteritis in Germany 2001-2009: eight seasons of routine surveillance. Epidemiol Infect. 2014;142(1):63-74.

33. Desai R, Hembree CD, Handel A, Matthews JE, Dickey BW, McDonald S, et al. Severe outcomes are associated with genogroup 2 genotype 4 norovirus outbreaks: a systematic literature review. Clin Infect Dis. 2012;55(2):189-93.

34. Hall AJ, Wikswo ME, Manikonda K, Roberts VA, Yoder JS, Gould LH. Acute gastroenteritis surveillance through the National Outbreak Reporting System, United States. Emerg Infect Dis. 2013;19(8):1305-9.

35. Leshem E, Wikswo M, Barclay L, Brandt E, Storm W, Salehi E, et al. Effects and clinical significance of Gll.4 Sydney norovirus, United States, 2012-2013. Emerging Infect Dis. 2013;19(8):1231-8.

36. Allen DJ, Adams NL, Aladin F, Harris JP, Brown DW. Emergence of the GIl-4 Norovirus Sydney 2012 strain in England, winter 2012-2013. PLoS One. 2014;9(2):e88978

37. Ho EC, Cheng PK, Lau AW, Wong AH, Lim WW. Atypical norovirus epidemic in Hong Kong during summer of 2006 caused by a new genogroup II/4 variant. J Clin Microbiol. 2007:45(7):2205-11.

38. Rosenthal NA, Lee LE, Vermeulen BA, Hedberg K, Keene WE, Widdowson MA et al. Epidemiological and genetic characteristics of norovirus outbreaks in long-term care facilities, 2003-2006. Epidemiol Infect. 2011;139(2):286-94.

39. Lopman BA, Reacher MH, Vipond IB, Sarangi J, Brown DW. Clinical manifestation of norovirus gastroenteritis in health care settings. Clin Infect Dis. 2004:39(3):318-24.

40. Bok K, Green KY. Norovirus gastroenteritis in immunocompromised patients. N Engl J Med. 2012;367(22):2126-32. 
41. Ramani S, Atmar RL, Estes MK. Epidemiology of human noroviruses and updates on vaccine development. Curr Opin Gastroenterol. 2014;30(1):25-33.

42. Phillips G, Tam CC, Conti S, Rodrigues LC, Brown D, Iturriza-Gomara M, et al. Community incidence of norovirus-associated infectious intestinal disease in England: improved estimates using viral load for norovirus diagnosis. Am J Epidemiol. 2010;171(9):1014-22.

43. Hemming M, Rasanen S, Huhti L, Paloniemi M, Salminen M, Vesikari T. Major reduction of rotavirus, but not norovirus, gastroenteritis in children seen in hospital after the introduction of RotaTeq vaccine into the National Immunization Programme in Finland. Eur J Pediatr. 2013;172(6):739-46.

44. Payne DC, Vinje J, Szilagyi PG, Edwards KM, Staat MA, Weinberg GA, et al. Norovirus and medically attended gastroenteritis in U.S. children. N Engl J Med. 2013;368(12):1121-30.

45. Gastanaduy PA, Hall AJ, Curns AT, Parashar UD, Lopman BA. Burden of norovirus gastroenteritis in the ambulatory setting-United States, 2001-2009. J Infect Dis. 2013;207(7):1058-65.

46. Koo HL, Neill FH, Estes MK, Munoz FM, Cameron A, Dupont HL, et al. Noroviruses: The Most Common Pediatric Viral Enteric Pathogen at a Large University Hospital After Introduction of Rotavirus Vaccination. J Pediatr Infect Dis Soc. 2013;2(1):57-60.

47. Becker-Dreps S, Bucardo F, Vilchez S, Zambrana LE, Liu L, Weber DJ, et al. Etiology of childhood diarrhea after rotavirus vaccine introduction: a prospective, population-based study in Nicaragua. Pediatr Infect Dis J. 2014;33(11):1156-63.

48. Bucardo F, Reyes Y, Svensson L, Nordgren J. Predominance of norovirus and sapovirus in Nicaragua after implementation of universal rotavirus vaccination. PLoS One. 2014;9(5):e98201.

49. Payne RFD, Vedio A, Cope A, Pratt G, Tunbridge A. "It's Just a Virus' - Viral Illness in Older People: Prevention and Management. Rev Clin Gerontol. 2013;23(2):11.

50. Jones TF. When diarrhea gets deadly: a look at gastroenteritis outbreaks in nursing homes. Clin Infect Dis. 2010;51(8):915-6.

51. Hall AJ, Curns AT, McDonald LC, Parashar UD, Lopman BA. The roles of Clostridium difficile and norovirus among gastroenteritis-associated deaths in the United States, 1999-2007. Clin Infect Dis. 2012;55(2):216-23.

52. Mattner F, Sohr D, Heim A, Gastmeier P, Vennema H, Koopmans M. Risk groups for clinical complications of norovirus infections: an outbreak investigation. Clin Microbiol Infect. 2006;12(1):69-74.

53. Goller JL, Dimitriadis A, Tan A, Kelly H, Marshall JA. Long-term features of norovirus gastroenteritis in the elderly. J Hospital Infect. 2004;58(4):286-91.

54. Caruso C, Buffa S, Candore G, Colonna-Romano G, Dunn-Walters D, Kipling D, et al. Mechanisms of immunosenescence. Immun Ageing. 2009;6:10,

55. Gustavsson L, Andersson LM, Lindh M, Westin J. Excess mortality following community-onset norovirus enteritis in the elderly. J Hospital Infect. 2011;79(1):27-31

56. Maziere S, Couturier P, Gavazzi G. Impact of functional status on the onset of nosocomial infections in an acute care for elders unit. J Nutrit Health Aging. 2013;17(10):903-7.

57. Marx A, Shay DK, Noel JS, Brage C, Bresee JS, Lipsky S, et al. An outbreak of acute gastroenteritis in a geriatric long-term-care facility: combined application of epidemiological and molecular diagnostic methods. Infect Control Hospital Epidemiol. 1999;20(5):306-11.

58. Blazevic V, Lappalainen S, Nurminen K, Huhti L, Vesikari T. Norovirus VLPS and rotavirus VP6 protein as combined vaccine for childhood gastroenteritis. Vaccine. 2011;29(45):8126-33.

59. Herbst-Kralovetz M, Mason HS, Chen Q. Norwalk virus-like particles as vaccines. Expert Review Vacc. 2010;9(3):299-307.

60. Velasquez LS, Shira S, Berta AN, Kilbourne J, Medi BM, Tizard I, et al. Intranasal delivery of Norwalk virus-like particles formulated in an in situ gelling, dry powder vaccine. Vaccine. 2011;29(32):5221-31.

61. Atmar RL, Estes MK. Norovirus vaccine development: next steps. Expert Review Vacc. 2012;11(9):1023-5.

62. Debbink K, Lindesmith LC, Baric RS. The State of Norovirus Vaccines. Clin Infect Dis. 2014;58(12):1746-52.

63. Werber D, Hille K, Frank C, Dehnert M, Altmann D, Muller-Nordhorn J, et al. Years of potential life lost for six major enteric pathogens, Germany, 2004-2008. Epidemiol Infect. 2013;141(5):961-8.

64. Huhulescu S, Kiss R, Brettlecker M, Cerny RJ, Hess C, Wewalka G, et al. Etiology of acute gastroenteritis in three sentinel general practices, Austria 2007. Infection. 2009;37(2):103-8.
65. Fernandez J, de Ona M, Melon S, Alvarez-Arguelles ME, Boga JA. Noroviruses as cause of gastroenteritis in elderly patients. Aging Clin Exp Res. 2011;23(2):145-7.

66. Tian G, Jin M, Li H, Li Q, Wang J, Duan ZJ. Clinical characteristics and genetic diversity of noroviruses in adults with acute gastroenteritis in Beijing, China in 2008-2009. J Med Virol. 2014;86(7):1235-42.

67. Manso CF, Torres E, Bou G, Romalde JL. Role of norovirus in acute gastroenteritis in the Northwest of Spain during 2010-2011. J Med Virol. 2013;85(11):2009-15

68. van Asten $L$, Siebenga J, van den Wijngaard C, Verheij $R$, van Vliet $H$, Kretzschmar M, et al. Unspecified gastroenteritis illness and deaths in the elderly associated with norovirus epidemics. Epidemiol (Cambridge, Mass). 2011;22(3):336-43.

69. Haustein T, Harris JP, Pebody R, Lopman BA. Hospital admissions due to norovirus in adult and elderly patients in England. Clin Infect Diseases. 2009:49(12):1890-2.

70. Lopman BA, Hall AJ, Curns AT, Parashar UD. Increasing rates of gastroenteritis hospital discharges in US adults and the contribution of norovirus, 1996-2007. Clin Infect Dis. 2011;52(4):466-74.

71. Chui KK, Jagai JS, Griffiths JK, Naumova EN. Hospitalization of the elderly in the United States for nonspecific gastrointestinal diseases: a search for etiological clues. Am J Public Health. 2011;101(11):2082-6.

72. Ruzante JM, Majowicz SE, Fazil A, Davidson VJ. Hospitalization and deaths for select enteric illnesses and associated sequelae in Canada, 2001-2004. Epidemiol Infect. 2011;139(6):937-45.

73. Al-Thani A, Baris M, Al-Lawati N, Al-Dhahry S. Characterising the aetiology of severe acute gastroenteritis among patients visiting a hospital in Qatar using real-time polymerase chain reaction. BMC Infect Dis. 2013:13(1):329.

74. Chan MC, Leung TF, Kwok AK, Lee N, Chan PK. Characteristics of patients infected with norovirus Gll.4 Sydney 2012, Hong Kong, China. Emerg Infect Dis. 2012;20(4):658-61.

75. Tang MB, Chen CH, Chen SC, Chou YC, Yu CP. Epidemiological and molecular analysis of human norovirus infections in Taiwan during 2011 and 2012. BMC Infect Dis. 2013;13:338.

76. Rovida F, Campanini G, Piralla A, Adzasehoun KM, Sarasini A, Baldanti F. Molecular detection of gastrointestinal viral infections in hospitalized patients. Diagn Microbiol Infect Dis. 2013;77(3):231-5.

77. van Asten L, van den Wijngaard C, van Pelt W, van de Kassteele J, Meijer A, van der Hoek W, et al. Mortality attributable to 9 common infections: significant effect of influenza A, respiratory syncytial virus, influenza B, norovirus, and parainfluenza in elderly persons. J Infect Dis. 2012;206(5):628-39.

78. Harris JP, Edmunds WJ, Pebody R, Brown DW, Lopman BA. Deaths from norovirus among the elderly, England and Wales. Emerg Infect Dis. 2008;14(10):1546-52

79. Schmid D, Kuo HW, Simons E, Kanitz EE, Wenisch J, Allerberger F, et al. All-cause mortality in hospitalized patients with infectious diarrhea: Clostridium difficile versus other enteric pathogens in Austria from 2008 to 2010. J Infect Public Health. 2014;7(2):133-44.

80. Verhoef L, Koopmans M, VAN Pelt W, Duizer E, Haagsma J, Werber D, et al. The estimated disease burden of norovirus in The Netherlands. Epidemiol Infect. 2013;141(3):496-506

81. Lynn SJ, Toop JM, Hanger HC, Millar ND. Norovirus outbreaks in a hospital setting: The role of infection control. N Z Med J. 2004;117(1189):U771.

82. Spackova M, Altmann D, Eckmanns T, Koch J, Krause G. High level of gastrointestinal nosocomial infections in the german surveillance system, 2002-2008. Infect Control Hospital Epidemiol. 2010;31(12):1273-8.

83. Kirk MD, Fullerton KE, Hall GV, Gregory J, Stafford R, Veitch MG, et al. Surveillance for outbreaks of gastroenteritis in long-term care facilities, Australia, 2002-2008. Clin Infect Dis. 2010:51(8):907-14.

84. Kirk MD, Veitch MG, Hall GV. Gastroenteritis and food-borne disease in elderly people living in long-term care. Clin Infect Dis. 2010;50(3):397-404.

85. Greig JD, Lee MB. Enteric outbreaks in long-term care facilities and recommendations for prevention: a review. Epidemiol Infect. 2009;137(2):145-55.

86. Utsumi M, Makimoto K, Quroshi N, Ashida N. Types of infectious outbreaks and their impact in elderly care facilities: a review of the literature. Age Ageing. 2010;39(3):299-305.

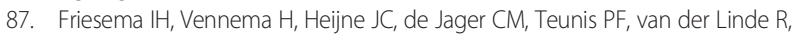
et al. Differences in clinical presentation between norovirus genotypes in nursing homes. J Clin Virol. 2009;46(4):341-4. 
88. Davis CA, Vally H, Beard FH. Norovirus in residential care facilities: does prompt notification of outbreaks help? Communicable Diseases Intelligence Quarterly Report. 2011;35(2):162-7.

89. Trivedi TK, DeSalvo T, Lee L, Palumbo A, Moll M, Curns A, et al. Hospitalizations and mortality associated with norovirus outbreaks in nursing homes, 2009-2010. JAMA. 2012;308(16):1668-75.

90. Franck KT, Fonager J, Ersboll AK, Bottiger B. Norovirus epidemiology in community and health care settings and association with patient age, Denmark. Emerg Infect Dis. 2014;20(7):1123-31.

91. Morton VK, Thomas MK, Mc ES: Estimated hospitalizations attributed to norovirus and rotavirus infection in Canada, 2006-2010. Epidemiol Infect. 2015:1-10

92. Kambhampati A, Koopmans M, Lopman BA. Burden of norovirus in healthcare facilities and strategies for outbreak control. J Hospital Infect. 2015;89(4):296-301.

93. MacCannell T, Umscheid CA, Agarwal RK, Lee I, Kuntz G, Stevenson KB, et al. Guideline for the prevention and control of norovirus gastroenteritis outbreaks in healthcare settings. Infect Control Hospital Epidemiol. 2011;32(10):939-69.

94. de Wit MA, Koopmans MP, Kortbeek LM, Wannet WJ, Vinje J, van Leusden F, et al. Sensor, a population-based cohort study on gastroenteritis in the Netherlands: incidence and etiology. Am J Epidemiol. 2001;154(7):666-74.

95. Trivedi TK, Desai R, Hall AJ, Patel M, Parashar UD, Lopman BA. Clinical characteristics of norovirus-associated deaths: A systematic literature review. Am J Infect Control. 2013;41(7):654-7.

96. Gibbons CL, Mangen MJ, Plass D, Havelaar AH, Brooke RJ, Kramarz P, et al. Measuring underreporting and under-ascertainment in infectious disease datasets: a comparison of methods. BMC Public Health. 2014;14:147.

97. Sakon N, Yamazaki K, Nakata K, Kanbayashi D, Yoda T, Mantani M, et al. Impact of Genotype-Specific Herd Immunity on the Circulatory Dynamism of Norovirus: A 10-Year Longitudinal Study of Viral Acute Gastroenteritis. J Infect Dis. 2014;211(6):879-88.

98. de Wit MA, Kortbeek LM, Koopmans MP, de Jager CJ, Wannet WJ, Bartelds Al, et al. A comparison of gastroenteritis in a general practice-based study and a community-based study. Epidemiol Infect. 2001;127(3):389-97.

99. OECD. Long-term Care: Growing Sector, Multifaceted Systems. In: Help wanted? Providing and paying for long-term care. 2011. p. 37-60.

100. Global Health and Aging. In.: WHO, NIA, NIH; 2011: 31.

101. Gavazzi G, Krause KH. Ageing and infection. Lancet Infect Dis. 2002;2(11):659-66.

102. Vesikari T, Blazevic V. Norovirus Vaccine: One Step Closer. J Infect Diseases. 2014;211(6):853-5.

103. Bernstein DI, Atmar RL, Lyon GM, Treanor JJ, Chen WH, Jiang X, et al. Norovirus Vaccine Against Experimental Human Gll.4 Virus IIIness: A Challenge Study in Healthy Adults. J Infect Dis. 2014;211(6):870-8.

104. Bartsch SM, Lopman BA, Hall AJ, Parashar UD, Lee BY. The potential economic value of a human norovirus vaccine for the United States. Vaccine. 2012;30(49):7097-104.

105. Harris JP, Lopman BA, O'Brien SJ. Infection control measures for norovirus: a systematic review of outbreaks in semi-enclosed settings. J Hospital Infect. 2010;74(1):1-9.

106. Talbot HK, Zhu Y, Chen Q, Williams JV, Thompson MG, Griffin MR. Effectiveness of influenza vaccine for preventing laboratory-confirmed influenza hospitalizations in adults, 2011-2012 influenza season. Clin Infect Dis. 2013;56(12):1774-7.

107. Centers for Disease Control and Prevention. What You Should Know and Do this Flu Season If You Are 65 Years and Older. September 3, 2014. Available at http://www.cdc.gov/flu/about/disease/65over.htm. Accessed 31 October 2014

108. Thompson WW, Comanor L, Shay DK. Epidemiology of seasonal influenza: use of surveillance data and statistical models to estimate the burden of disease. J Infect Dis. 2006;194 Suppl 2:S82-91.

109. Shahid H, Welch CA, Minnich LL, Daly SB, Wilhelm CM, Udall Jr JN. Gastrointestinal norovirus in the Charleston, West Virginia area-2007: birth to 99 years of age. Pediatr Infect Dis J. 2009;28(10):918-20.

110. Leshem E, Barclay L, Wikswo M, Vega E, Gregoricus N, Parashar UD, et al. Genotype Gl.6 norovirus, United States, 2010-2012. Emerg Infect Dis. 2013;19(8):1317-20.
111. Hall AJ, Lopman BA, Payne DC, Patel MM, Gastanaduy PA, Vinje J, et al. Norovirus disease in the United States. Emerg Infect Dis. 2013;19(8):1198-205.

112. Arias C, Sala MR, Dominguez A, Torner N, Ruiz L, Martinez A, et al. Epidemiological and clinical features of norovirus gastroenteritis in outbreaks: a population-based study. Clin Microbiol Infect. 2010;16(1):39-44.

113. Phillips G, Tam CC, Rodrigues LC, Lopman B. Prevalence and characteristics of asymptomatic norovirus infection in the community in England. Epidemiol Infect. 2010;138(10):1454-8.

114. Tseng CY, Chen CH, Su SC, Wu FT, Chen CC, Hsieh GY, et al. Characteristics of norovirus gastroenteritis outbreaks in a psychiatric centre. Epidemiol Infect. 2011;139(2):275-85.

\section{Submit your next manuscript to BioMed Central and take full advantage of:}

- Convenient online submission

- Thorough peer review

- No space constraints or color figure charges

- Immediate publication on acceptance

- Inclusion in PubMed, CAS, Scopus and Google Scholar

- Research which is freely available for redistribution 